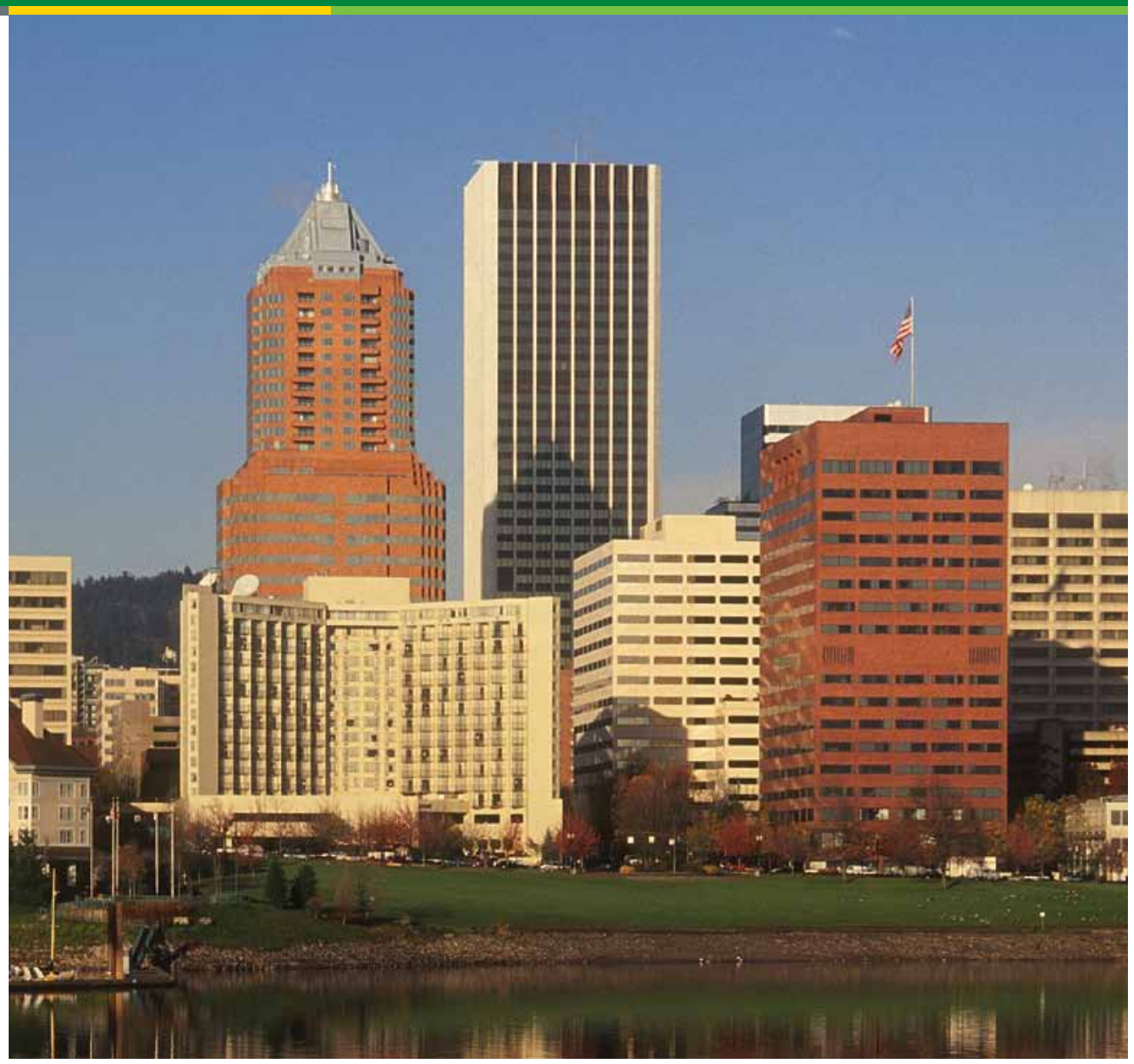

\title{
A Guide to Performance Contracting with ESCOs
}




\section{A Guide to Performance Contracting with ESCOs}

Prepared by

Pacific Northwest National Laboratory

Michael Baechler

Portland Energy Conservation, Inc.

Lia Webster

September 27, 2011

Prepared for

U.S. Department of Energy

under Contract DE-AC05-76RL01830

PNNL-20939

Pacific Northwest National Laboratory

Richland, Washington 99352

This report was prepared as an account of work sponsored by an agency of the United States Government. Neither the United States Government nor any agency thereof, nor Battelle Memorial Institute, nor any of their employees, makes any warranty, express or implied, or assumes any legal liability or responsibility for the accuracy, completeness, or usefulness of any information, apparatus, product, or process disclosed, or represents that its use would not infringe privately owned rights. Reference herein to any specific commercial product, process, or service by trade name, trademark, manufacturer, or otherwise does not necessarily constitute or imply its endorsement, recommendation, or favoring by the United States Government or any agency thereof, or Battelle Memorial Institute. The views and opinions of authors expressed herein do not necessarily state or reflect those of the United States Government or any agency thereof. 


\section{Contents}

A Guide to Performance Contracting with ESCOs ........................................... 1

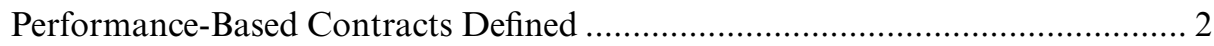

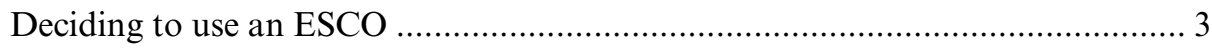

The Performance-Based Contracting Process ………........................................ 5

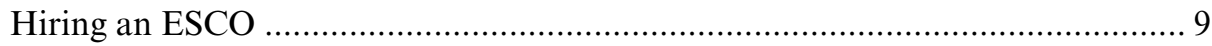

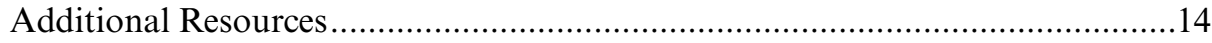

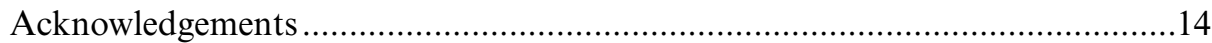

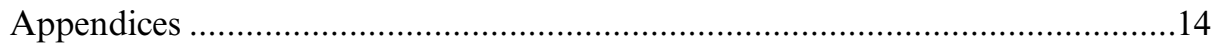




\section{A Guide to}

\section{Performance \\ Contracting with ESCOs}

A performance contract allows you to improve the energy performance of your building by partnering with an energy services company (ESCO) to enhance building operations and save energy. An ESCO is a company that identifies energy improvements, provides the capital required and installs improvements, offers turn-key

Oregon State University's 40 year old, 250,000ft2 Hatfield Marine Science Center is now reaping the benefits of a guaranteed savings project that is being paid for by the project's energy savings.

The project upgraded lighting and improved the energy management system to deliver energy annual energy savings of more than $277,000 \mathrm{kWh}$ valued at more than $\$ 15,600$ per year.

The value of the enhanced safety and comfort of the new systems are hard to quantify, but the facility's manager identifies these less tangible benefits as an important part of the project's success.

This energy savings performance contract was a first for the Oregon higher education system, and its success has paved the way for more projects. More details of this project can be found at http://www.oregon.gov/ENERGY/CONS/ ESPC/.

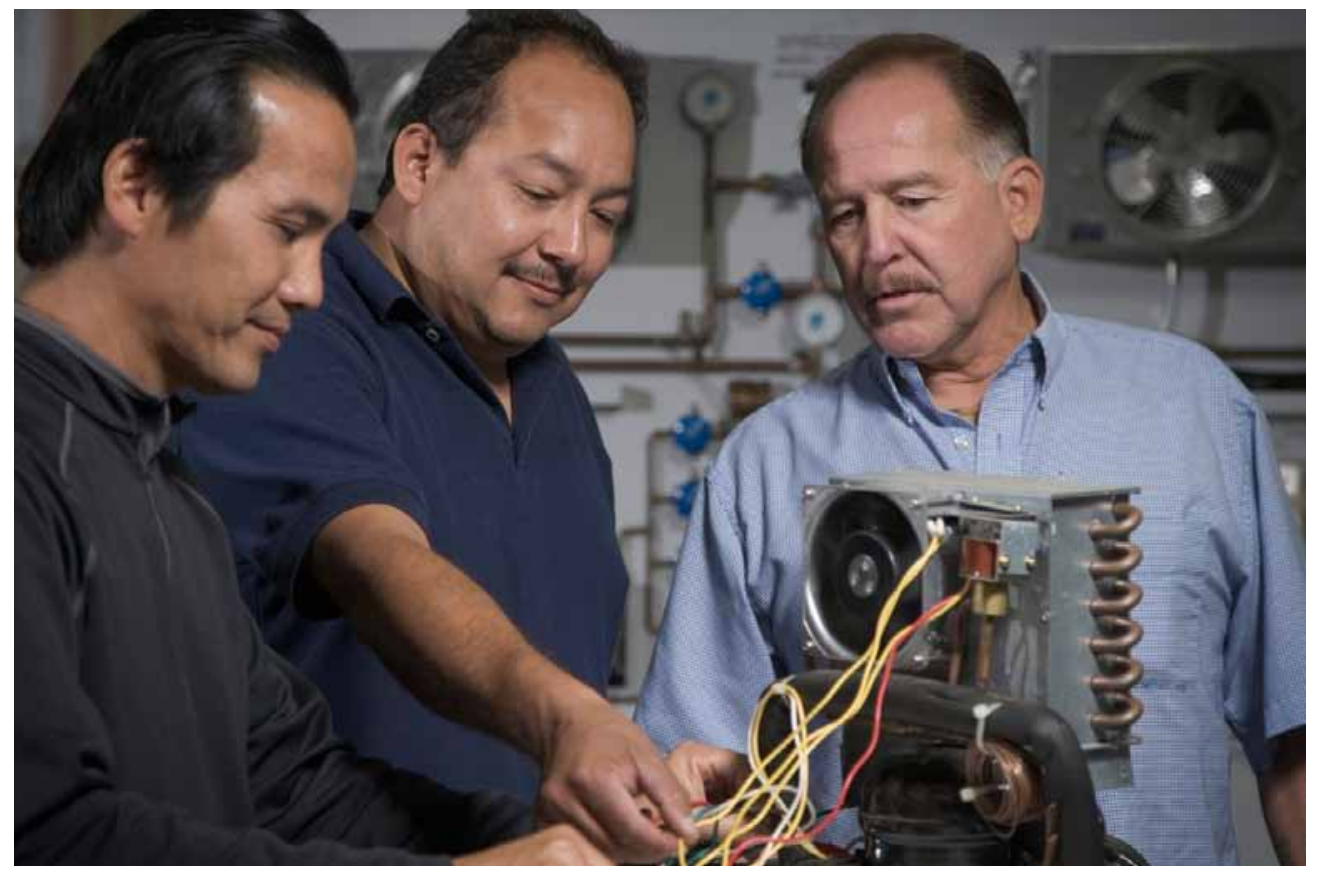

O\&M is one of many services that ESCOs offer.

installation services, and guarantees energy savings. Companies pay the ESCO back over a period of years from the energy cost savings generated from the project. The ESCO monitors the performance of the project for the life of the contract and verifies the energy savings which result. In some cases, the ESCO may also operate and maintain the new equipment and systems.

Hiring an ESCO is a proven strategy for identifying and implementing energy saving capital improvements, while managing risks inherent in such projects. ESCOs can provide a range of services, from an energy audit to a third-party financed turn-key project with a comprehensive set of measures and guaranteed energy savings. Their specialty is the performance contract that shifts some of the project's performance risk to the ESCO in exchange for allowing the ESCO to capture a share of the savings.

Key benefits to working with ESCOs include improved building performance, options for project financing and risk management, and access to expertise, new equipment and training with little to no upfront cost. Performance contracts can apply to an individual building, campuses, or whole portfolios.

This guide describes the benefits offered by ESCOs and the things to consider when selecting and contracting with your provider. ESCOs have long served government markets. Performance contracting can be an effective investment approach for the private sector as well. 


\section{COMMON TERMS}

Energy services company (ESCO) - a

company that identifies energy improvements, provides the capital required to install improvements, offers turn-key installation services, and guarantees energy savings

Performance contract - a legal framework used by ESCOs which clearly details project expectations and details procedures that will be utilized

Energy efficiency measures (EEMs) adjustments to building systems and controls, or equipment installations that result in lower energy use

Investment grade audit - a

comprehensive energy audit that seeks to identify all cost-effective investment opportunities through a combination of engineering analysis of energy-using systems and economic analysis of possible energy saving measures

\section{Performance-Based Contracts Defined}

Energy saving performance contracts form the legal framework between an ESCO and your company. These relationships typically span multiple years and may include both energy management and other capital upgrades in your facility.

Performance based contracting has a strong presence in the United States, Asia and Europe. In the US, the ESCO industry has about $\$ 4$ billion per year in revenue, with the majority of work being conducted in public and institutional buildings.

A bundle of energy services are included in a performance contract, which is why many facility owners and managers choose to manage their energy projects through ESCOs.

The core energy services may include:

- Energy audits (which include recommendations for energy efficiency measures or "EEMs")

- Project scope development

- Engineering and design

- Financing

- Equipment selection and purchasing

- Construction management

- Commissioning

- Project documentation

- Training owner's operating staff

- Guarantee of savings through ongoing monitoring and verification activities

Other services that are often provided under this type of contract include:

- Operations and maintenance of equipment

- Utility commodities/ power negotiations and purchasing

- Energy management services 


\section{Deciding to use an ESCO}

An ESCO can provide a bundle of services that can help you simplify and streamline your energy management efforts. However, utilizing an ESCO and a performance contract does not work for every situation. Is an ESCO right for you? Some of the key questions that should be evaluated include:

- Will ownership of the building remain the same for the foreseeable future?

- Do I have a project champion inhouse that will drive the project to completion?

- Does my organization need a guarantee on the project's performance to move forward?

- Will my organization be willing to contract with an ESCO, including the time and effort required to develop and negotiate a project?

- Would the availability of capital financing be beneficial?

- Do I need external expertise to identify and scope the energy project?

- Would implementing the project unassisted, including contracting and construction management, be challenging for in-house staff?

- Do I still need to get high-level buyin for the project internally?

- Will our in-house staff need help to properly operate and maintain the new equipment?

If you answered yes to six or more questions, you should strongly consider using an ESCO.

\section{Types of ESCOs and Performance Contracts}

ESCOs differ in their ownership structure and in the markets they target. ESCOs can be independent or affiliated with other companies, such as equipment suppliers, utility company subsidies or engineering companies.
ESCOs with market focus may have a local geographic focus or work nationally. Market focused ESCOs work in specific sectors (commercial, industrial, residential, schools, hospitals, government) and concentrate on one or more technical arenas including lighting, HVAC, controls or industrial processes.

When looking for an ESCO partner, you may find it useful to first consider which of these ESCO types will best meet your needs, including providing the project structure desired

In general, there are four primary types of performance contracts. Your choice of contract depends largely on whether you need guaranteed savings, whether you require external financing, and your risk tolerance related to building performance.

\section{Guaranteed savings}

Guaranteed savings contracts are the most common form of performance contracts, and are heavily used by the government. These contracts are characterized by:

- A fixed term with a fixed payment schedule in which the ESCO ensures the savings will meet or exceed a minimum level.

- Financing typically provided by the ESCO, but may include capital investment from the Owner.

- ESCO sees no added benefit if savings estimates are exceeded.

\section{Shared savings}

In shared savings projects, which are less frequently executed than other approaches, cost savings from the project are shared between the building owner and the ESCO.

- Arrangements vary, but payments to the ESCO may be a fixed percentage of savings, a minimum fee plus a share of the savings, or a scaled fee that decreases over time as the ESCO recoups its investment.
- The ESCO typically provides the capital investment and assumes most of the risk.

- Both the ESCO and the owner may see additional monetary benefit if savings estimates are exceeded.

\section{No guaranteed savings}

In this type of contract, the ESCO provides the energy audit, design and construction management and commissioning, typically at a fixed fee, but does not guarantee the energy savings or performance of the project.

- In this case, the owner accepts all of the project risk, similar to a design build arrangement.

- The owner may provide capital directly from cash reserves or financing.

\section{Chauffauge or Utility Purchase Agreements}

Chauffauge is a French word meaning 'heating' and is used to describe an arrangement popular with ESCOs in Europe and present in the US.

- In this arrangement, the ESCO owns, operates, and maintains the energy using equipment.

- The owner buys the end-use (heating, air-conditioning, lighting, etc.) for an agreed-upon rate and period of time.

- The ESCO may also negotiate with fuel and power suppliers to arrange purchase agreements, and maintains those relationships and payments. 


\section{Sources of Financing for Performance Contracts}

The source of financing can vary and is often provided by large institutional lenders, although in some cases capital may come from facility owners, the ESCO, or some combination. Financial incentives and rebates offered by local utilities are often leveraged where available and help buy-down project costs. Additionally, the structure of the debt may vary, and some contracts allow the financing to be off the balance sheet and not accrue towards your debt limits.

Self-Financed - Companies can work with an ESCO and still provide project funding. These funds may come from outside financiers or from internal budgets, or both. This is the most common approach used in performance contract projects. This format provides the simplest contracting approach, and can still include a performance guarantee from the ESCO. Interest rates may be lower than other options, although your company carries the debt.

ESCO-Financed - In some cases, an ESCO will provide funding for a project from their own capital. This is most commonly an option when working with very large service providers. It is more common, however, for the ESCO to arrange third-party financing.

Third-Party Financed - Third-party financing indicates the funding for the project does not come from the facility owner or the ESCO. There are sometimes challenges, however, to securing funding for energy projects. Additionally rates and terms may be affected by the reputation of the ESCO.

Lease-purchase agreements - Lease arrangements are common under third-party or ESCO financing where the financier leases equipment to the facility owner. At the end of the contract, equipment ownership is transferred to the facility owner.
Bonds and Loan Pools - State and other government entities may be eligible for special financing mechanisms, including loan pools and bonds. There is an indication, however, that these financing tools are becoming more widely available in the private sector.

\section{Project Costs}

The size of projects varies widely with project costs. Lawrence Berkeley National Lab (LBNL) and National Association of Energy Services Companies (NAESCO) reported that project investments range significantly - from $\$ 200,000$ to greater than $\$ 20 \mathrm{M}$. The median cost of more than 1,400 reported projects was $\$ 700,000$.

The overall costs of performance contracting in government markets tend to be much more expensive than in private sector. Median costs for private performance contracts were $\$ 1.40$ /square foot compared to $\$ 2.40 /$ square foot for government contracts. These costs do not include the internal time required by the owner's staff to negotiate and establish the performance contract.

Key areas that will drive overall project costs include the following:

- Energy Audit - The scope and level of detail of the energy audit can be a big driver in costs. Establishing criteria for cost-effectiveness prior to conducting the audit can help limit the scope to pursuing only viable projects. Reported costs for detailed energy audits may vary from $\$ 0.12$ up to $\$ 0.50$ per square foot, depending on the size and complexity of the building. Economies of scale tend to apply for larger facilities.

- Equipment costs - Depending on the retrofits needed, equipment costs can be significant. For example, if your building requires a new chiller, this retrofit may be more expensive and less cost-effective than others, but may be necessary.
- Equipment mark-up and ESCO profit

- ESCOs often include an overhead and profit factor that applies to all equipment and may also pertain to reoccurring services as well. These factors should be clarified during project development and may be negotiable.

- Interest Rates - Interest rates have a huge impact on the overall cost-effectiveness and viability of a performance contract project, as interest rates can add substantial expense over the term of a project.

- Construction Costs - Performance contract projects are typically fixed cost projects, and the ESCO is responsible for determining construction costs and defining a budget. Most performance contracts are a fixed-price design/build contract, and you would assume little responsibility for cost overruns.

- M\&V Costs - Ongoing measurement and verification activities will be cost line items for the project. Annual $\mathrm{M} \& \mathrm{~V}$ costs range from about 2 percent to 10 percent of annual cost savings. One challenge in crafting an effective verification strategy is balancing $\mathrm{M} \& \mathrm{~V}$ costs and technical rigor in quantifying the savings.

- Other ongoing costs - Any new additional costs related to expanded operations and maintenance activities will show as ongoing costs during the performance period. In addition, equipment repair and replacement may be built into the financial plan of the project when needed.

- Delays - Both your team and the contractor can cause project delays, which can add cost to the project (e.g., construction interest, remobilization). 


\section{The Performance-Based Contracting Process}

A performance-based contracted project generally has five general phases. A description of the activities associated with a typical project is shown in the table below.

\begin{tabular}{|c|c|c|}
\hline Project Phase & Project Milestone(s) & Project Activities \\
\hline 1) Project Development & $\begin{array}{l}\text { - Feasibility Study } \\
\text { - ESCO Selection } \\
\text { - Audit contract } \\
\text { - Energy audit/project } \\
\text { scope development } \\
\text { - Contract negotiations \& } \\
\text { Financing }\end{array}$ & $\begin{array}{l}\text { - } \text { Initial project scoping } \\
\text { - ESCOs are evaluated and } \\
\text { proceed } \\
\text { - Execute contract for } \\
\text { energy audit } \\
\text { - Evaluate facility and } \\
\text { develop project scope } \\
\text { - Nail down technical } \\
\text { details of project } \\
\text { execution and secure } \\
\text { financing }\end{array}$ \\
\hline 2) Implementation & $\begin{array}{l}\text { - Installation of energy } \\
\text { saving equipment or } \\
\text { implementation of } \\
\text { energy saving measures }\end{array}$ & $\begin{array}{l}\text { - Final design, equipment } \\
\text { purchasing and } \\
\text { construction } \\
\text { management }\end{array}$ \\
\hline 3) Acceptance Phase & $\begin{array}{l}\text { - Post-installation } \\
\text { commissioning and } \\
\text { verification }\end{array}$ & $\begin{array}{l}\text { - Commission affected } \\
\text { systems and begin } \\
\text { savings verification } \\
\text { procedures } \\
\text { - Staff training }\end{array}$ \\
\hline 4) Performance Period & $\begin{array}{l}\text { - Ongoing operations } \\
\text { and maintenance } \\
\text { - Periodic measurement } \\
\text { and verification }\end{array}$ & $\begin{array}{l}\text { Proper operations and } \\
\text { maintenance of existing } \\
\text { and new equipment } \\
\text { - Verify and quantify } \\
\text { accrued energy savings }\end{array}$ \\
\hline 5) Project close-out & - Project close-out & $\begin{array}{l}\text { - Financial obligations are } \\
\text { resolved }\end{array}$ \\
\hline
\end{tabular}

\section{Project Development}

The Project Development phase includes several key milestones and/or deliverables.

- Feasibility Study. The feasibility study is often provided by ESCO free of charge to scope the potential energy savings projects. Often, these initial project scoping reports are included as a part of a response to an RFP you issue.

- Audit Contract. Once an ESCO has been selected to perform an in-depth energy audit, a simple contract is executed. The purpose of this agreement is to clarify the scope of the audit, to set a not-to-exceed cost for executing the investigation, and to clarify payment terms. Typically, the cost of the energy audit will be included in the total financed amount if the project proceeds through implementation.

- Energy audit/project scope development. The energy audit identifies energy and related cost savings opportunities at the facility. The ESCO will work with the owner to create custom packages of measures. 
- Contract Negotiations. Project expectations should be clarified as part of contracting with an ESCO. Responsibilities of the parties, as well as project costs, should be well-defined. ESCOs are experts at performance contracts, and early agreement on scope, contract length, ESCO mark-up and profit, rigor of verification activities, and operations and maintenance issues will make these negotiations much faster. It is important to note that performance contracts can be complex, depending on the scope of the work and the contracting arrangement desired. Acquiring outside expertise on the contracting terms and obligations may be appropriate, and there are consultants experienced in navigating performance contracts.

\section{Implementation Phase}

Once the contract has been awarded, the ESCO will finalize the design, purchase the equipment, and work with sub-contractors to install equipment and ensure it is working as intended. Typically, the ESCO will provide turn-key services including construction management, commissioning, and measurement and verification.

\section{Acceptance Phase}

The Acceptance Phase consists of commissioning the affected equipment and systems to ensure proper operation and adherence to the design intent. Commissioning may include existing equipment and systems that may be affected by the operation or savings achieved by new equipment. Commissioning is typically performed by the ESCO, but facility owners may hire an independent commissioning agent.

Typically, the ESCO will provide training to the facility staff on the new equipment including operating and maintenance issues.

Initial savings verification activities may include surveys, inspections, spot measurements, and short- and long-term metering. The project is accepted after these commissioning and savings verification activities have been completed.

\section{Performance Period}

The performance period is the time from project acceptance to project close out. During this time period the ESCO must ensure the project's performance, including proper operations and maintenance. Additionally, the ESCO will determine

DOE's Federal Energy Management Program (FEMP) has detailed information on addressing O\&M issues in performance contracts:

Planning and Reporting for Operations \& Maintenance in Federal Energy Saving Performance Contracts, available at: http://www1.eere.energy.gov/femp/pdfs/ planning_om_espcs.pdf actual savings achieved through execution of the verification activities. The typical duration of performance contracts is 10 years, but shorter contracts in the 5 year range are becoming more frequent .

\section{Ongoing Operations \& Maintenance}

Operations and maintenance (O\&M) activities are critical to ensuring that guaranteed savings persist throughout the term of the performance contract. O\&M activities may be conducted by the owner or the ESCO, and can be a source of cost savings. To help ensure success, the O\&M plan for new equipment should coordinate with the O\&M approach for existing equipment.

In addition to energy savings, a performance contract project may generate additional cost savings. Related cost savings can result from avoided expenditures for operations, maintenance, equipment repair, or equipment replacement due to the performance contract project. 
Sources of energy-related savings include:

- Avoided current or planned capital expense (e.g., equipment replacement)

- Elimination of a maintenance contract or reduction in O\&M staff due to transfer of responsibility for O\&M and/or repair and replacement to the ESCO during the performance period

- Avoided repair and replacement costs as a result of replacing equipment

\section{Measurement and Verification (M\&V)}

A strong measurement and verification $(\mathrm{M} \& \mathrm{~V})$ approach is a core requirement of a successful performance contract arrangement. The goal of $M \& V$ is to reduce your risk by providing a mechanism to evaluate the performance of a project throughout the term of the contract. Any savings guarantee is defined by the $M \& V$ activities, whose function is to verify and quantify savings. The challenge of $M \& V$ is to balance $\mathrm{M} \& \mathrm{~V}$ costs with the value of increased certainty in the cost savings from the conservation measure.

\section{$\mathrm{M} \& \mathrm{~V}$ can:}

- Quantify energy savings from a project

- Monitor equipment performance

- Ensure savings persist and identify additional savings

- Verify proper operations and maintenance (O\&M)

- Verify cost savings and/or performance guarantee(s) are met

- Allocate risks to the appropriate parties

Measuring and verifying savings from performance contracting projects requires special project planning and engineering activities. $M \& V$ is an evolving science, although common practices exist. These practices are documented in several guidelines, including the primary industry reference entitled International Performance Measurement \& Verification Protocol (IPMVP 2007).

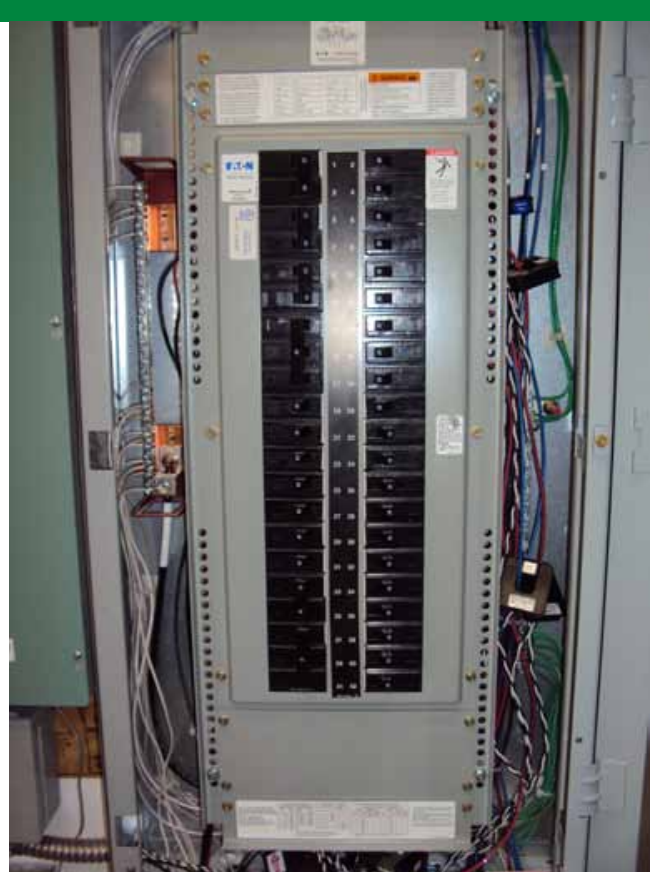

M\&V reduces your risk by ensuring energy savings.

\section{M\&V GUIDELINES INCLUDE}

- International Performance Measurement \& Verification Protocol (IPMVP 2007) from http://www.evoworld.org/

- FEMP’s M\&V Guidelines: Measurement and Verification for Federal Energy Projects Version 3.0 (2008)from http:// www1.eere.energy.gov/femp/financing/ superespcs_measguide.htm/

- ASHRAE Guideline 14: Measurement of Energy and Demand Savings (2002) from $h t t p: / / w w w$.ashrae.org 


\section{Steps to Verify Savings}

Regardless of the $M \& V$ guideline followed, similar steps are taken to verify the potential for the installed energy efficiency measures (EEMs) to achieve savings. These steps include:

\begin{tabular}{|c|c|c|}
\hline Project Phase & M\&V Step & Description of key activities \\
\hline \multirow[t]{2}{*}{$\begin{array}{l}\text { Project } \\
\text { Development }\end{array}$} & $\begin{array}{l}\text { Step 1: Define the } \\
\text { baseline conditions } \\
\text { accurately }\end{array}$ & $\begin{array}{l}\text { Documentation of existing conditions via } \\
\text { the energy audit, including: } \\
\text { - Whole building energy use } \\
\text { - Equipment inventory and conditions } \\
\text { - Occupancy } \\
\text { - Sub-metered energy consumption rates } \\
\text { - Control strategies \& operational data }\end{array}$ \\
\hline & $\begin{array}{l}\text { Step 2: Develop } \\
\text { project-specific } \\
\text { Measurement \& } \\
\text { Verification (M\&V) and } \\
\text { Commissioning plans }\end{array}$ & $\begin{array}{l}\text { Documentation of all assumptions and } \\
\text { sources of data and details of planned } \\
\text { activities related to commissioning and } \\
\text { savings verification: } \\
\text { - What will be verified and when } \\
\text { - Who will conduct the M\&V and } \\
\text { commissioning activities } \\
\text { - Schedule for all commissioning and } \\
\text { verification activities } \\
\text { - Details of engineering analysis } \\
\text { performed and how all sources of } \\
\text { savings will be calculated } \\
\text { - Utility rates } \\
\text { - O\&M responsibilities } \\
\text { - Reporting requirements }\end{array}$ \\
\hline Implementation & $\begin{array}{l}\text { Step 3: } \\
\text { Commission the } \\
\text { systems }\end{array}$ & $\begin{array}{l}\text { Prior to project acceptance, execute the } \\
\text { commissioning plan to ensure installed } \\
\text { systems perform according to design. } \\
\text { Results are typically documented in a } \\
\text { Commissioning Report. }\end{array}$ \\
\hline Acceptance & $\begin{array}{l}\text { Step 4: } \\
\text { Conduct Post- } \\
\text { installation verification }\end{array}$ & $\begin{array}{l}\text { Begin to execute the M\&V plan, which will } \\
\text { likely include ongoing activities for the } \\
\text { length of the contract. Verification } \\
\text { strategies include surveys, inspections, } \\
\text { spot measurements, and short- and long- } \\
\text { term metering. }\end{array}$ \\
\hline $\begin{array}{l}\text { Performance } \\
\text { Period }\end{array}$ & $\begin{array}{l}\text { Step 5: } \\
\text { Periodic Verification }\end{array}$ & $\begin{array}{l}\text { Ongoing verification activities are } \\
\text { scheduled on a periodic basis to quantify } \\
\text { savings and to ensure the installed } \\
\text { equipment/systems have been properly } \\
\text { maintained and continue to operate } \\
\text { correctly. Results are typically } \\
\text { documented in M\&V reports. }\end{array}$ \\
\hline
\end{tabular}

For guidance on verifying O\&M, repair and replacement, and reporting responsibilities in a performance contract, see:

\section{How to Determine and Verify Operating and Maintenance (O\&M) Savings in Federal Energy Savings Performance Contracts}

http://www1.eere.energy.gov/femp/ pdfs/10_4_determineverifyomsavings.pdf and

Operations \& Maintenance Best Practices: A Guide to Achieving Operational Efficiency

http://www1.eere.energy.gov/femp/pdfs/ omguide_complete.pdf 


\section{Project close-out}

At the end of a performance contract, all financial obligations between you, the $\mathrm{ESCO}$, and the financier are resolved. If lease arrangements were utilized, equipment ownership would be transferred to you at this time. Project close-out typically occurs at the end of the planned performance period, but may occur earlier if you terminate the project for convenience.

\section{Post-Project Operations and Maintenance}

After a performance contract has been closed out, all responsibility for operations, maintenance and repairs is assumed by the building owner. Depending on the level of duties the ESCO had assumed on the operations and maintenance activities, this may represent a significant shift for the site. Ensuring proper operations and maintenance after the performance contract is critical in ensuring the savings from the project continue to persist. It is important to plan ahead for this transition to ensure adequate staff is available and have been properly trained.

\section{Hiring an ESCO}

A performance contract can be a long and complex project that results in extra tasks and responsibilities for building personnel, and may eventually result in changes to operational procedures. To ensure the success of the project, it is essential that one or more members of the team are able and willing to act as the internal project "champion" who will defend and support the goals of the project at every phase of the project. The "champion" understands the goals and intended outcomes of the performance contract and is able to address the challenges and potential pitfalls that may arise so that the project stays on track.

Since a performance contract can take considerable effort and coordination, it is important that your project team is well prepared to handle all aspects of the process. Below is an overview of the key areas of responsibility for you and your team members.

The corporate project sponsor provides all supervision for the performance contract, including authorizing contractual agreements. Sponsors are responsible for ensuring the participation of staff, coordinating with contracting and legal representatives (internal or external), possibly consulting with financing specialists, engaging external technical expertise on ESPCs as needed and funding controls contractor, if needed. The project sponsor also works with the financier on project funding.

Building operators or engineers are also heavily involved in the process. They ensure the participation of building personnel and contractors as needed, provide input into the investigation process and assist the ESCO with the investigation. Investigation activities may include providing access to facilities, gathering building and operational data, supporting functional testing, and helping the ESCO to understand the mechanical systems and the building control strategies. The building operator may also oversee or assist with $\mathrm{M} \& \mathrm{~V}$ and commissioning, and ensure proper equipment maintenance throughout the project.

\section{Selecting an ESCO}

The process of selecting an ESCO involves identifying potential partners, requesting proposals, conducting a site walk-through with the ESCOs and then selecting the best ESCO for the job.

ESCOs can provide a range of services. Understanding the strengths and weaknesses of your own organization can help your project team define your service needs, which may include project identification, design and construction, maintenance, and/or finance.

\section{ESCO ORGANIZATIONS}

Two leading organizations within the ESCO industry are national Association of Energy Services Companies (NAESCO) and the Energy Services Coalition (ESC):

http://www.naesco.org

http://www.energyservicescoalition.org 
An initial scope of work determined through a feasibility study will also help you get the right partner for the job. If the feasibility study indicates that half of the energy use at your facility is due to one process, you'll want to select an ESCO partner with expertise in that process. With this understanding of your service and technical requirements, you can then see what ESCOs are out there to meet those needs.

There are many resources that can help you compile a list of candidate ESCOs serving your area. Such resources include: your utility company, state and federal agencies, and ESCO industry organizations. Some government agencies have already compiled a list of approved ESCOs which can provide a useful starting point even if your agency or business does not require an approved ESCO. Once you've created an initial list, you can then narrow it to a group of qualified ESCOs based on their expected ability to satisfy the service and technical requirements that you've identified.

\section{Developing an RFP}

Government projects often require selection of an ESCO through an RFP process, but private sector facility owners may also find the process useful in comparing the qualifications, services and pricing offered by multiple ESCOs. One goal of the RFP process is to inform the ESCOs as early as possible of any expectations you may have regarding scope and technical approach of the project. Ultimately the objective is to select the most well suited ESCO to provide the desired services and meet other costing and technical criteria.

The diagram below outlines the typical process used to select an ESCO.

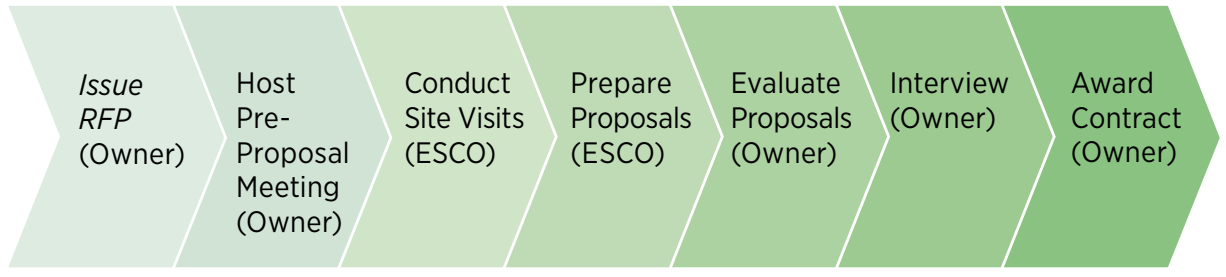

RFP for an ESCO, identifying the lead for each activity within the process

The RFP should:

- Describe project goals and initial scope

- nclude a thorough description of the facilities to be included in the project

- Communicate requirements for project and services

- Include a request for qualifications

- Include a request of the proposed project approach

- Request each ESCO perform a site visit to assess project feasibility

- Include a request for initial project scope, cost and fees

- Describe the procedure, criteria and metrics that will be used to select the winning proposal (i.e., outline the weighting of importance between experience, pricing, and technical approach)

- Describe opportunities for submittal of questions, project schedule, and contractual constraints 
After the RFP is released to the ESCOs, it is advisable to provide an opportunity for those interested in bidding to get to know more about your facility and your project ideas. This opportunity is usually provided through a pre-proposal meeting and site visit. In the meeting, a question and answer session gives bidders an opportunity to clarify their understanding of the RFP. Through the site visit bidders can determine the feasibility of applying various energy saving measures at your facility.

A sample Request for Proposal is provided as an appendix in Volume 2. The practices described here and represented in the sample have worked well for other organizations, but it's important to recognize that there is flexibility in this process. It can be tailored to the needs of your organization and project. Ultimately, the RFP's sole requirement is that it enables your team to evaluate which ESCO is best suited to deliver the services that you require, within the constraints faced by your project.

\section{Selection process}

Selection of the winning proposal is generally made by a selection committee, which applies the evaluation procedures and criteria set forth in the RFP. Thus, early in the RFP development process it is important to determine who will join the selection committee and what criteria will be used to judge the proposals. The selection committee will typically include many members of your project team, other members of your organization that must sign off on the project, and any other interested stakeholders. Typically, the same group of people will also be responsible for accepting the final scope of work and contracting details. A range of perspectives will be valuable when evaluating the proposals and can help ensure team buy-in.

The evaluation of ESCO initial proposals compares the relative strength of each proposal in terms of technical approach, experience and qualifications of the team, pricing, and compliance with other requirements set forth in the RFP. Given that the full scope of the project is yet to be determined, it is reasonable to give criteria relating to the ESCO qualifications and experience a greater weight in the evaluation than cost and pricing, which remain uncertain. This may, however, be the best point in time to address key pricing issues such as equipment mark-up and ESCO overhead and profit. The description of the proposed approach should include details as to how baseline energy use and energy savings will be determined, as well as the proposed structure of ESCO fees for performance payments and any other core services such as ongoing verification and operations.

By comparing the proposals, ranking on these criteria and applying weights to each category, you can select a short list of the top ranking proposals.

The final step in selecting an ESCO partner is to determine which top ranked ESCO provides a good fit with your project team. After the proposals are reviewed, this fit can be evaluated through an interview with one or more of the top ranked ESCOs. One approach to this interview is to prepare one set of questions for all candidates, and another that is specific to the candidate and addresses any questions that remain after review of the proposal. When the evaluators have interviewed and scored each interviewee, a combined score from the proposal and interview can be used to determine the top-ranked ESCO. That ESCO can then be invited to negotiate a contract for conducting an investment grade energy audit that may lead to a performance contract.

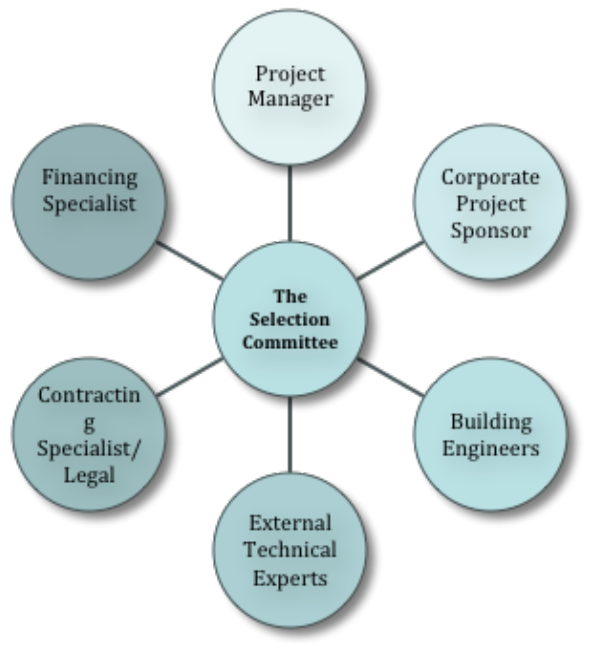

Sample composition of an ESCO selection committee.

\section{WHAT MAKES A QUALIFIED ESCO?}

Samples of previous work, interviews of past clients and a careful review of the experience of key personnel can be used to determine whether the ESCO has successful experience working with similar facilities. Further evidence of qualifications includes documentation from completed projects, client references, and proof of the firm's financial and organizational stability. 


\section{Contracting}

Carefully crafted contract terms are required to ensure appropriate risk allocation between you and the ESCO. Though contracting an ESCO shares many features of contracting for other design and installation services, there are a few twists that may be unfamiliar. Exact contract terms will depend on how you plan to finance your project and whether the ESCO's compensation will vary according to the actual energy savings achieved by the project. Many organizations choose to separate contracting for the energy audit from contracting for subsequent phases of the project.

Having selected the most qualified ESCO for your job, the next step in the process is to conduct an investment grade audit that will support decisions about what energy efficiency measures to pursue. The contract for this audit is relatively straightforward. It specifies the scope and schedule of the audit, the ESCO's fee for conducting the audit, and the format and content of the deliverables. Assuming your ESCO conducted a feasibility study during the proposal period, the scope of this investment grade audit should be relatively clear. The deliverables from such an audit are the results of the ESCO's analysis and the ESCO's proposal for installing and commissioning the energy saving measures identified. This contract can incorporate a clause so that the fee for the audit is paid from the energy savings, if the owner decides to contract with the ESCO to implement the energy saving measures. A sample audit contract is provided as an appendix in Volume 2.

Completion of the investment grade audit will provide a clear picture of the energy saving opportunities on your property, their costs, and estimates of the energy savings that each will deliver. This is where it can get a bit complicated, as terms are established in a contract for the ESCO to install, commission, and verify the energy savings from the selected measures. On the simpler end, there may be utility rebates that reduce the cost of implementing the measures. In this case, the contract should specify how this benefit will be shared by you and the ESCO. Complexities may arise when payments to the ESCO will be based on energy savings. In these cases, the contract must clearly specify the method(s) of calculating savings and a procedure should any disputes as to savings arise. A sample performance contract is provided as an appendix in Volume 2.

\section{Risk Management}

On a performance contract project, a number of typical financial, operational, and performance issues must be considered. These factors are outlined below and should be addressed in the contract, M\&V plan or both.

It is important to recognize that everyone, including ESCOs, is reluctant to assume responsibility for factors they cannot control. Stipulating certain parameters in the contract can align responsibilities but can also transfer risk. Clear understanding and agreement on these issues is key to ensuring a fair and equitable partnership.

\section{Financial Issues}

Future utility rates may be identified by checking with your utility or state regulatory body. Energy escalation rates are also predicted by the DOE's Energy Escalation Rate Calculator available through http://www1.eere.energy.gov/ femp/information/download_blcc. html\#eerc
Depending on the structure of the performance contract, a number of factors may have financial implications for you and/or the ESCO. These issues should be addressed in the performance contract documents.

Evaluate the interest rates a specific lender or ESCO can provide to ensure the best rate possible. Higher interest rates will increase the project's cost and term.

Energy rates fluctuate. If energy costs are significantly overvalued, you may end up paying more than the savings are worth, and existing energy budgets may not cover the payments required. Carefully evaluate the energy rate structures funda- 
mental to all payments and ensure that escalation rates applied to energy values are conservative.

Project costs are another consideration. The ESCO determines construction costs and assumes responsibility for cost overruns, but you should ensure that project expectations will still be met. Also, $M \& V$ costs increase with the rigor of reported savings. Clarify your required level of assurance in reported savings and any measurement preferences early in the project; then work with the ESCO to determine savings verifications and the impact on $M \& V$ costs.

\section{Operational Issues}

Operational issues should be addressed in the $\mathrm{M} \& \mathrm{~V}$ plan as they are fundamental in calculating energy use and realizing the energy savings from performance contract projects.

For example, changes in equipment operating hours and load can show up as increases or decreases in "savings." Clarify whether operating hours are to be measured during the baseline and stipulated, or based on ongoing or periodic measurements. Also clarify how equipment loads will be determined and how facility changes affecting loads will be handled.

Some EEMs require user participation to generate savings (e.g., control settings). The ESCO may be unwilling to invest in these measures without including monitoring and training to mitigate risk. Your contract should address how changes in operating procedures will be handled, and how proper operations will be assured (e.g., operator training).

Finally, a number of EEMs are affected by weather. Use of typical weather data is one approach to mitigate risks from weather.

\section{Performance Issues}

Equipment performance is also critical to energy use calculations and savings determinations. Typically, the ESCO is responsible for equipment performance. The contractor may need to demonstrate that the improvements meet expected performance levels including specified equipment capacity, standards of service, and efficiency. Preventative maintenance activities can impact performance and life of equipment, and while repair and replacement of ESCO-installed equipment is negotiable, this is often tied to project performance.

The M\&V plan should state roles and responsibilities for initial and long-term performance, including who is responsible for replacing failed components or equipment throughout the term of the contract. (If equipment life is shorter than the term of the contract, consider scheduling replacements in the financial plan.)

The M\&V plan should also clarify how performance will be verified, and what will be done if performance does not meet expectations or if inadequate preventive maintenance impacts performance.

\section{KEY CONSIDERATIONS IN RISK MANAGEMENT}

Operational Issues

Operating Hours

Load

Weather

\section{Financial Issues \\ Interest Rates \\ Energy Prices \\ Construction Costs \\ M\&V Costs \\ Delays \\ Major Facility Changes \\ Performance Issues \\ Equipment Performance \\ Maintenance \& Repair \\ Equipment Replacement}




\section{Additional Resources}

When hiring an ESCO, it is important to find an agent that can provide the necessary services and has experience with comparable facilities. Choosing a financing option that fits your organization's needs, carefully weighing cost and risk trade-offs, and being mindful of energy savings calculations and their associated assumptions are also critical in this process.

Resources are widely available to building owners considering ESCOs and performance contracting and we encourage you to review additional literature before embarking upon your energy saving project. Below are some websites that provide useful and up to date information that can be used to assist you through the performance contracting process:

1. US Department of Energy (extensive documentation of federal experience with performance contracts): http://www1.eere.energy. gov/femp/financing/espcs.html

2. The Building Owners \& Managers Association's ESPC Toolkit: http://www.boma.org/Resources/BEPC/Pages/default.aspx

3. National Association of Energy Service Companies (industry organization): http://www.naesco.org

4. Energy Services Coalition: http://www.energyservicescoalition.org/resources/model/index.html\#Pre-Qualify

5. International Performance Measurement \& Verification Protocol (IPMVP 2007): http://www.evo-world.org/

\section{Acknowledgements}

The information in this document is drawn from several existing guides and reports:

- California Energy Commission. How to Hire an Energy Services Company; 2000. http://www.energy.ca.gov/reports/efficiency_ handbooks/400-00-001D.PDF

- FEMP M\&V Guidelines v3.0. U.S. DOE, Prepared by Nexant, Inc. M\&V Guidelines: Measurement and Verification for Federal Energy Projects, Version 3.0; 2008. http://www1.eere.energy.gov/femp/pdfs/mv_guidelines.pdf

- State of Idaho Performance Contracting Program. Request for Proposal for Energy Performance Contracting Service; Technical Energy Audit \& Project Development Agreement; Energy Performance Contract. http://adm.idaho.gov/pubworks/perfcontracting/

- State of Hawaii. Guide to Energy Performance Contracting (EPC), 2011 Revision; 2011. http://hawaii.gov/dbedt/info/energy/ efficiency/state/performance/HawaiiEPCGuide.2-3-11.FINAL.5.30pm.pdf

\section{Appendices}

Sample RFP: Request for Proposal for Energy Performance Contracting Service;

Sample audit contract: Technical Energy Audit \& Project Development Agreement;

Sample performance contract: Energy Performance Contract

Appendices in separate volume.

\section{(Endnotes)}

'Satchwell, A. et al., Lawrence Berkeley National Lab. A Survey of U.S. ESCO Industry: Market Growth and Development from 2008 to $2011 ; 2010$. http://eetd.lbl.gov/ea/ems/reports/lbnl-3479e.pdf

${ }^{2}$ Langois, P., Econoler International. The Development of Third Party Financing in Western Countries and CECs (A presentation). http://www.resourcesaver.com/file/toolmanager/O105UF209.pdf Accessed June 23, 2011.

${ }^{3}$ White, P., Johnson Controls. An Awakening in Energy Efficiency: Financing Private Sector Building Retrofits; 2010. http://www.johnsoncontrols.com/ publish/etc/medialib/jci/be/solutions_for_your/private_sector.Par.68730.File.dat/Financing\%20PrivateSector\%20whitepaper\%20FINAL.pdf

${ }^{4}$ Goldman, C. et al., Lawrence Berkeley National Lab. Review of U.S. ESCO Industry Market Trends: An Empirical Analysis of Project Data; 2005. http://eetd.llbl.gov/ea/ems/reports/52320.pdf

${ }^{5}$ Satchwell, A. et al., Lawrence Berkeley National Lab. A Survey of U.S. ESCO Industry: Market Growth and Development from 2008 to $2011 ; 2010$. http://eetd.lbl.gov/ea/ems/reports/lbnl-3479e.pdf

${ }^{6}$ California Energy Commission. How to Hire an Energy Services Company; 2000. http://www.energy.ca.gov/reports/efficiency_handbooks/400-00001D.PDF

${ }^{7}$ LBNL 2005 ESCO Industry Market trends

${ }^{8}$ Adopted from FEMP M\&V Guidelines v3.0. U.S. DOE, Prepared by Nexant, Inc. M\&V Guidelines: Measurement and Verification for Federal Energy Projects, Version 3.0; 2008. http://www1.eere.energy.gov/femp/pdfs/mv_guidelines.pdf 


\section{ve ENEROY}

Energy Efficiency \& Renewable Energy
EERE Information Center

1-877-EERE-INF (1-877-337-3463)

www.eere.energy.gov/informationcenter

For more information, visit:

commercialbuildings.energy.gov/alliances
Commercial Building Initiative 